\title{
Projected Slowdown of Antarctic Bottom Water Formation in Response to Amplified Meltwater Contributions
}

\author{
VÉRONIQUe LAGO AND MATTHEW H. ENGLAND \\ Climate Change Research Centre, and Australian Research Council Centre of Excellence for Climate System Science, University \\ of New South Wales, New South Wales, Australia
}

(Manuscript received 20 September 2018, in final form 6 June 2019)

\begin{abstract}
The sinking and recirculation of Antarctic Bottom Water (AABW) are a major regulator of the storage of heat, carbon, and nutrients in the ocean. This sinking is sensitive to changes in surface buoyancy, in particular because of freshening since salinity plays a greater role in determining density at cold temperatures. Acceleration in Antarctic ice-shelf and land-ice melt could thus significantly impact the ventilation of the world's oceans, yet future projections do not usually include this effect in models. Here we use an ocean-sea ice model to investigate the potential long-term impact of Antarctic meltwater on ocean circulation and heat storage. The freshwater forcing is derived from present-day estimates of meltwater input from drifting icebergs and basal melt, combined with RCP2.6, RCP4.5, and RCP8.5 scenarios of projected amplification of Antarctic meltwater. We find that the additional freshwater induces a substantial slowdown in the formation rate of AABW, reducing ventilation of the abyssal ocean. Under both the RCP4.5 and RCP8.5 meltwater scenarios, there is a near-complete shutdown of AABW formation within just 50 years, something that is not captured by climate model projections. The abyssal overturning at $\sim 30^{\circ} \mathrm{S}$ also weakens, with an $\sim 20$-yr delay relative to the onset of AABW slowdown. After 200 years, up to $\sim 50 \%$ of the original volume of AABW has disappeared as a result of abyssal warming, induced by vertical mixing in the absence of AABW ventilation. This result suggests that climate change could induce the disappearance of present-day abyssal water masses, with implications for the global distribution of heat, carbon, and nutrients.
\end{abstract}

\section{Introduction}

The ocean's abyssal layers are rich in nutrients and carbon, and the gradual recirculation of these waters back to the surface constitutes a profoundly important component of the recycling of carbon and nutrients in the ocean. The abyssal oceans are almost exclusively composed of Antarctic Bottom Water (AABW), which is formed in the Southern Ocean through the sinking of dense shelf water. This water sinks to the ocean's abyssal layers; eventually upwelling nutrients and carbon back toward the surface. The formation of AABW is thus important to global biological productivity and the ocean carbon cycle.

Variations in AABW formation and properties are closely tied to changes in upper-ocean density (Sarmiento et al. 1998; de Lavergne et al. 2014; Zanowski et al. 2015), as surface buoyancy controls the sinking of water over the shelf, which eventually

Corresponding author: Véronique Lago, v.lago@unsw.edu.au cascades into the abyssal ocean to form AABW. At the temperature range of the Antarctic margin, variations in surface density are primarily controlled by changes in salinity, more so than temperature, due to the nonlinearity of the equation of state (Gordon 1971; Gordon 2001). In this way, any variation in surface freshwater fluxes around Antarctica has the potential to play a substantial role in controlling AABW formation rates. Enhanced land-ice melt could thus alter the cycling of heat, carbon, and nutrients by the global ocean.

None of the models from phase 5 of the Coupled Model Intercomparison Project (CMIP5) includes submodels for ice-shelf or ice-sheet melt, and thus CMIP5 models potentially underestimate the effect of meltwater in global projections of ocean circulation change. Analysis of runoff trends from CMIP5 models suggests little change over the next few centuries (Agosta et al. 2015), but this only includes precipitation effects, excluding the contribution from melting of Antarctica's ice sheets and ice shelves. Consequently, while projected 
climate scenarios in CMIP5 models suggest little impact on AABW over the next century (Downes and Hogg 2013; Heuzé et al. 2015), this remains highly uncertain, as the role of additional projected estimates of meltwater input remains unexplored. Recent estimates from dynamic ice-sheet simulations suggest that Antarctica could contribute around $0.30 \mathrm{~m}$ (Ritz et al. 2015), 0.10$0.39 \mathrm{~m}$ (Golledge et al. 2015), or up to $1.05 \pm 0.30 \mathrm{~m}$ of sea level rise by 2100 (DeConto and Pollard 2016), with a possible multicentury contribution of $15.65 \pm$ $2.00 \mathrm{~m}$ by 2500 (DeConto and Pollard 2016). This rate of ice melt would imply a strong surface freshening around Antarctica, yet relatively little is known about the resultant changes in the global overturning circulation from this freshwater input. In this study we will use a coupled ocean-sea ice model to explore the impact of such a meltwater addition on the circulation around Antarctica, with a focus on the overturning of AABW and the long-term response of the abyssal ocean. Our experiments also seek to quantify the impact of this missing forcing in the context of CMIP5 future projections.

Recent studies suggest that AABW production may have slowed considerably over the past few decades as evidenced by the observed warming of AABW (Johnson et al. 2008; Purkey and Johnson 2012). Some studies have suggested that the recent warming of AABW could be driven by a change in the density classes of $\mathrm{AABW}$ due to a freshening of source waters, and that the formation rate itself might not have changed much (Azaneu et al. 2013; van Wijk and Rintoul 2014). When calculated using a volumetric analysis of AABW (with AABW defined as colder than $0^{\circ} \mathrm{C}$ ), the production of this water mass has declined by an estimated $8.2 \pm 2.6 \mathrm{~Sv}\left(1 \mathrm{~Sv} \equiv 10^{6} \mathrm{~m}^{3} \mathrm{~s}^{-1}\right)$ over the period 1993-2006 (Purkey and Johnson 2012). Despite evidence for a change in AABW production over the past few decades, it remains unclear what has controlled this, as both surface warming and surface freshening could be the driving factors, and surface freshening itself could be the result of any of precipitation, sea-ice, ice-shelf, or land-ice melt trends.

While this trend of warming and freshening of abyssal waters over the last few decades (Purkey and Johnson 2010, 2012; Kouketsu et al. 2011) is consistent with a slowdown in AABW production, it remains unclear whether the trends are due to a slowdown in AABW production, or whether they simply indicate ventilation of abyssal layers by warmer and fresher surface waters (Azaneu et al. 2013; van Wijk and Rintoul 2014). Even though the exact mechanisms driving trends in AABW properties are still yet to be determined, and may vary geographically, the changes are likely to be initiated by temperature and/or salinity changes at the surface of the Southern Ocean, such as those forced by ice melt or surface warming.

The goal of this study is to use a coupled ocean-sea ice model to evaluate the impact of Antarctic meltwater amplification on ocean circulation and abyssal water properties over a multicentury time scale. We purposefully employ a modeling platform comparable to the typical ocean-ice component of CMIP5 models. This will help us to estimate the impact of missing landice melt in CMIP5 future projections, both in terms of AABW overturning and temperature-salinity properties in the ocean interior. The rest of this paper is divided as follows: In section 2 we describe the model and experimental design. Section 3 evaluates the changes in $\mathrm{AABW}$ formation and properties along with the implied spatial change in ocean heat content and sea level rise. In section 4 , we discuss the implications of these results.

\section{Model and experimental design}

We use the Australian Community Climate and Earth System Simulator Ocean Model (ACCESS-OM 1.0; Bi et al. 2013) global ocean model to perform the experiments, which is based on the 2009 release of the NOAA/GFDL MOM4p1 code (Griffies 2009). Our configuration of the model uses $1^{\circ}$ resolution in the zonal and meridional directions, but with a meridional refinement of $1 / 3^{\circ}$ between $10^{\circ} \mathrm{S}$ and $10^{\circ} \mathrm{N}$, a cosinedependent resolution ranging from $14^{\circ}$ at $78^{\circ} \mathrm{S}$ to $1^{\circ}$ at $30^{\circ} \mathrm{S}$, and a tripolar grid north of $65^{\circ} \mathrm{N}$. There are 50 vertical levels ranging in thickness from $10 \mathrm{~m}$ in the upper ocean up to $333 \mathrm{~m}$ in the abyssal layers. The model configuration and physical parameterizations used in this study are the same as in Lago et al. (2016) and nearly the same as presented in Table 1 of Bi et al. (2013), with the only two exceptions being the vertical convection scheme and the reduction of nearequatorial vertical diffusion. The advection of tracers uses the multidimensional flux-limited scheme for conservative temperature, salinity, and age (Sweby 1984; Hundsdorfer and Trompert 1994). The horizontal friction uses a Smagorinsky isotropic biharmonic friction (Griffies and Hallberg 2000). The background vertical diffusivity is set to $1 \times 10^{-5} \mathrm{~m}^{2} \mathrm{~s}^{-1}$ globally, with a reduction tapered to $1 \times 10^{-4} \mathrm{~m}^{2} \mathrm{~s}^{-1}$ in the tropics at latitudes $20^{\circ} \mathrm{S}-20^{\circ} \mathrm{N}$. The submesoscale mixed layer restratification fjollows the scheme of FoxKemper et al. (2011). Vertical convection is handled implicitly using an enhanced vertical diffusivity following the scheme of Killworth et al. (1991). In the 
deep ocean, the background vertical mixing is set to $1 \mathrm{~m}^{2} \mathrm{~s}^{-2}$. In the upper ocean, vertical mixing follows the $k$-parameterization profile mixed layer scheme (Large et al. 1994). The neutral physics are parameterized following Gent and McWilliams (1990) with the isoneutral diffusivity set to $600 \mathrm{~m}^{2} \mathrm{~s}^{-2}$. Enhanced diffusion along isopycnal surfaces is also incorporated, following the scheme of Redi (1982). The tidal mixing parameterization in the abyssal ocean follows Simmons et al. (2004). Barotropic coastal tidal dissipation is incorporated following Lee et al. (2006). The shelf water overflows at high latitudes are parameterized using the sigma transport scheme of Beckmann and Döscher (1997).

The model was spun up for 500 years using the ocean surface normal year Coordinated Ocean-Ice Reference Experiments version 2 (CORE; Large and Yeager 2004, 2009). The model exhibits little water-mass drift in the control experiment subsequent to this spinup; any drift is of negligible magnitude compared to the scale of changes simulated in the meltwater anomaly experiments. Sea surface salinity (SSS) is restored to a seasonal climatology using a 15-day restoring time scale (surface layer thickness is $10 \mathrm{~m}$ ), with a maximum value of $0.5 \mathrm{psu}$ for the salinity difference being restored. The salinity restoring is applied via a virtual salt flux, which includes a zero net anomaly in total salt restored; this implies that the net salt added/removed is compensated globally. This compensation results in maximum changes of order $\sim 0.1$ psu north of the Antarctic Circumpolar Current.

As noted above, the model used in this study is essentially the ocean/sea ice component of the ACCESS1.0 coupled model (Bi et al. 2013) that was part of the CMIP5 intercomparison project. The control climate abyssal overturning circulation in the ACCESS1.0 coupled model $(8.4 \pm 1.7 \mathrm{~Sv})$ happens to be close to the CMIP5 multimodel mean $(10.0 \pm 6.7 \mathrm{~Sv})$, whereas the ACCESS1.0 North Atlantic Deep Water (NADW) strength is at the upper end of transport rates, with $\sim 23 \mathrm{~Sv}$ overturning simulated, as compared with the multimodel mean of $\sim 18 \mathrm{~Sv}$ (Wang et al. 2014). Despite the strong simulated baseline NADW production, the model's annual mean northward Atlantic Ocean heat transport at $26.5^{\circ} \mathrm{N}$ is $1.2 \mathrm{PW}$, within the error margin of the observed RAPID estimate $(1.33 \pm 0.4$ PW; Johns et al. 2011). In terms of a future RCP8.5 emissions scenario, the projected abyssal overturning slowdown in the ACCESS1.0 coupled model (2.4 Sv by 2100$)$ is nearly identical to the CMIP5 multimodel mean [2.2 Sv; see Fig. 8f of Heuzé et al. (2015)]. As noted above, however, future projected changes in CMIP5 models do not include the effects of additional meltwater input from the
Antarctic ice sheet and ice shelves. This is the focus of the current study.

Before analyzing the model-projected response to the addition of meltwater, it is important to assess how and where the model forms AABW. Like most CMIP5 models (Heuzé et al. 2015), AABW is formed in the ACCESS-OM 1.0 model by both high-salinity dense water overturn to the seafloor over the Antarctic shelf and subsequent downslope transport, as well as via open-ocean convection, most often in the Weddell Sea. To estimate the relative importance of the shelf and open-ocean convection in our model, we compare the respective surface areas of occurrence as well as the water-mass transformation occurring within these areas following the method of Brambilla et al. (2008). Here we define shelf convection as having a maximum mixed layer depth (MLD) reaching within the bottom two cells of the vertical grid for a bathymetry no deeper than $1000 \mathrm{~m}$, and open-ocean convection as having a maximum MLD $>2500 \mathrm{~m}$ with no restrictions on the local ocean depth. At the beginning of the experiments, the total area of convection as per these definitions is $56 \%$ over the shelf and $44 \%$ over the open ocean. Furthermore, the densest variety of bottom water is primarily formed over the shelf, with $74 \%$ of the water-mass transformation for neutral densities $>27.8 \mathrm{~kg} \mathrm{~m}^{-3}$ occurring over the shelf (derived from the analysis shown in Fig. 5b, which is discussed further below). In the real ocean, convection occurs almost exclusively over the Antarctic continental shelf, but most models of CMIP5 resolution exhibit unrealistic open-ocean deep convection (Heuzé et al. 2015). However, as we will see later in this study, the more realistic shelf-convection contribution to AABW is central to the simulated slowdown we obtain in response to added meltwater.

We consider a series of experiments in which we add meltwater around Antarctica between nominal years 2000 and 2200, following an exponential function fitted to approximately match the total amount of freshwater added under the projections of DeConto and Pollard (2016). For context with other estimates of Antarctic ice melt, the amount of meltwater estimated by DeConto and Pollard (2016) in the RCP4.5 and RCP2.6 scenarios happens to be nearly identical to that of the RCP8.5 and RCP2.6 scenarios of Golledge et al. (2015). No other anthropogenic forcing is included in our simulations as the goal of this study is to estimate the role of Antarctic meltwater in isolation of other factors. The freshwater is added with two different geographic distributions: the first uses the Antarctic runoff pattern applied in the CORE normal year forcing. The second employs a pattern that combines the basal melt estimates from Depoorter et al. (2013) with the iceberg melt estimates 


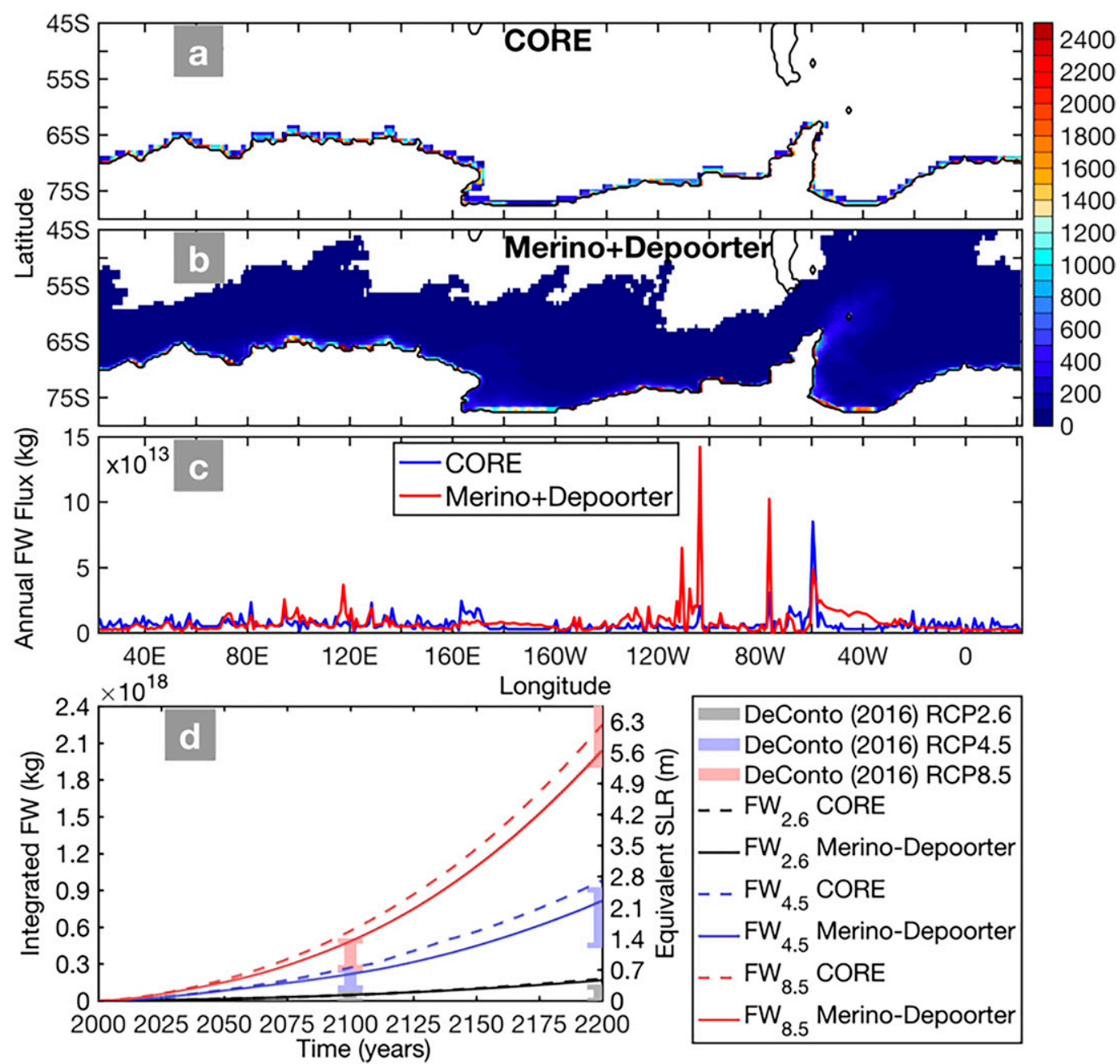

FIG. 1. (a) Runoff values $\left(\mathrm{kg} \mathrm{m}^{-2}\right)$ around the Antarctic margin in the CORE normal year forcing (NYF) climatology (Large and Yeager 2004, 2009) applied in the control experiment. (b) Pattern of applied meltwater anomalies $\left(\mathrm{kg} \mathrm{m}^{-2}\right)$ derived from combining the Depoorter et al. (2013) and Merino et al. (2016) basal and iceberg melt climatologies, averaged over an 11-yr simulation with daily averaged forcing during 1979-2011. (c) Meridionally integrated freshwater input $\left(10^{13} \mathrm{~kg}\right)$ from both the CORE-NYF runoff and the MerinoDepoorter meltwater rates, as a function of longitude. (d) Globally integrated net Antarctic freshwater input $\left(10^{18} \mathrm{~kg}\right)$ applied in each perturbation experiment (the details are in section 2$)$.

from Merino et al. (2016) (Figs. 1a-c). The combined pattern from Depoorter et al. (2013) and Merino et al. (2016) is hereinafter referred to as the MerinoDepoorter pattern. The basal meltwater is added artificially at the ocean surface through runoff whereas the iceberg melt is added via precipitation so that the freshwater input from drifting icebergs can be added away from the coast. Adding basal melt at the surface is not realistic, but it is a common approach in model studies that do not resolve ice-shelf cavities. Mathiot et al. (2017) developed a technique to parameterize basal melt through the water column within ice-shelf cavities and relative to adding at the surface. They showed that this impacts the properties and dynamics at the Antarctic shelf, but the difference does not penetrate into the deep ocean. To reduce the immediate removal of meltwater due to SSS restoring, a modified restoring field is updated each month with the additional freshwater from the experiment added. The total volume of freshwater added is targeted so that the net freshwater flux added to the model (i.e., the freshening less restoring terms) is equivalent to the DeConto and Pollard (2016) estimates (Fig. 1d). Each climate scenario experiment has the same net freshwater added for both the CORE and Merino-Depoorter cases; however there is more freshwater remaining in the CORE simulations 


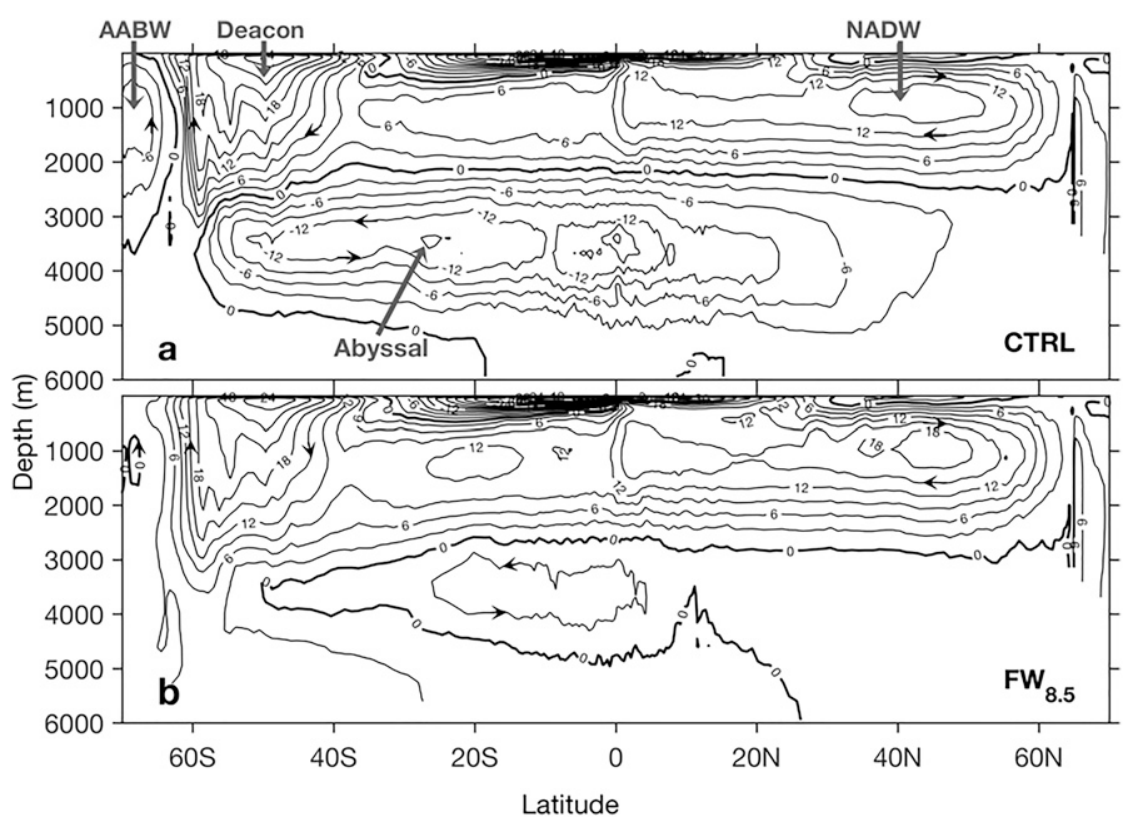

FIG. 2. Global meridional overturning streamfunction (MOC) in (a) the control experiment $\left(\mathrm{Sv} ; 1 \mathrm{~Sv}=10^{6} \mathrm{~m}^{3} \mathrm{~s}^{-1}\right.$ ) and (b) the $\mathrm{FW}_{8.5}$ experiment (applied with the Merino-Depoorter freshwater pattern) at year 2200. Arrowheads indicate the direction of the overturning circulation. The location of the overturning cells referred to in the text is indicated in (a).

(Fig. 1d) because the CORE pattern loses less freshwater from SSS restoring due to its more confined spatial extent (Figs. 1a,b).

The results obtained using the CORE freshwater pattern turn out to be consistent with the simulations applying the Merino-Depoorter pattern, indicating that the results are robust to this pattern of applied meltwater forcing; thus, only the results from the MerinoDepoorter freshwater simulations will be presented. The three experiments presented here are referred to as $\mathrm{FW}_{2.6}, \mathrm{FW}_{4.5}$, and $\mathrm{FW}_{8.5}$, where the meltwater added corresponds to the projections from DeConto and Pollard (2016) following their RCP2.6, RCP4.5, and RCP8.5 Antarctic ice melt simulations. A parallel control experiment was also performed with an identical model setup and surface forcing, but where no meltwater was added.

\section{Results and discussion}

\section{a. AABW formation}

The streamfunction of the global overturning circulation comprises two overturning cells linked to AABW (Fig. 2a). The southernmost cell adjacent to the Antarctic continent centered near $65^{\circ} \mathrm{S}$ will be referred to as the "AABW cell," and the deeper overturning cell centered near $30^{\circ} \mathrm{S}$ and $3500-\mathrm{m}$ depth will be referred to as the "abyssal cell." The AABW cell is controlled by AABW formation adjacent to Antarctica (mainly via shelf-water convection), whereas the abyssal cell is set by the total northward flow of water below $\sim 3500 \mathrm{~m}$ at $\sim 30^{\circ} \mathrm{S}$ (Fig. 2a). These two overturning cells nearly collapse in response to the added Antarctic meltwater in $\mathrm{FW}_{4.5}$ and $\mathrm{FW}_{8.5}$ (Fig. 2b). The maximum strength of the AABW cell exhibits a rapid slowdown $(\sim 75 \%$ of its original strength) within 30 years of model integration in $\mathrm{FW}_{8.5}$. A slowdown of $\sim 75 \%$ is reached after $50-60$ years for $\mathrm{FW}_{4.5}$ (Fig. 3a). The decline in the abyssal overturning strength has an $\sim 20$-yr lag relative to the reduction of the AABW cell and shows a more gradual decline thereafter (Fig. 3b). The difference in the overturning response time scales is due to different processes driving each cell; the AABW cell largely operates as a shorter-time-scale response to convective overturn adjacent to Antarctica, whereas the abyssal cell is controlled by density gradients across the ocean bottom layers, modulated by advective and diffusive adjustments. A more gradual response can also be seen in the reduction of AABW volume (Fig. 3c), because this change is controlled, to a large extent, by slower diffusive time scales.

In contrast to the rapid slowdown in AABW production seen in experiments $\mathrm{FW}_{4.5}$ and $\mathrm{FW}_{8.5}$, the $\mathrm{FW}_{2.6}$ experiment has a much more gradual decline of AABW formation rates (Fig. 3a). To examine any tipping point 


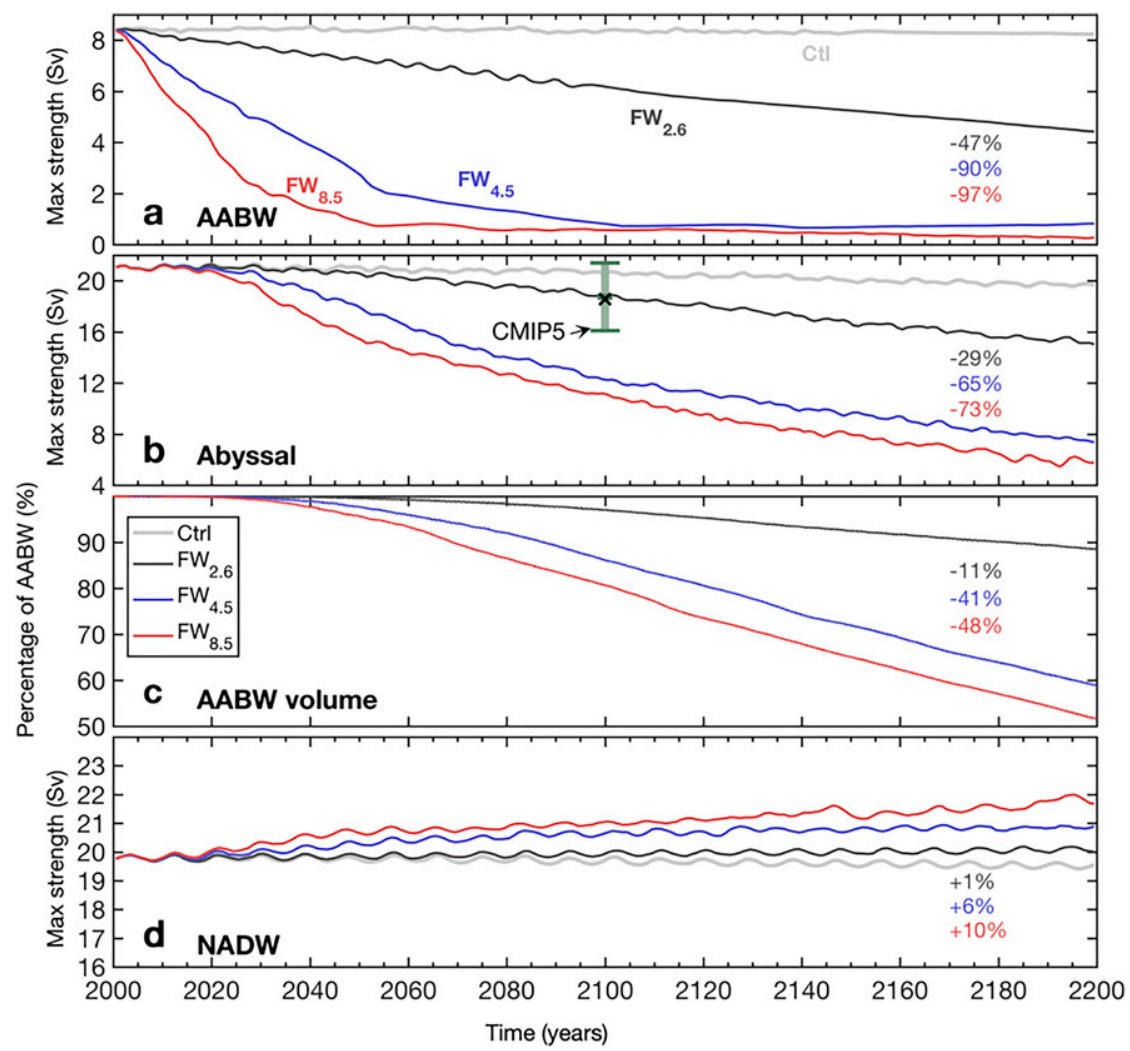

FIG. 3. Time series of the maximum strength of key overturning cells derived from the global MOC (Sv). The cells shown are (a) the AABW cell, defined as the maximum MOC strength south of $60^{\circ} \mathrm{S}$, (b) the abyssal cell, defined as the maximum MOC strength below $2500 \mathrm{~m}$, and (d) the NADW cell, defined as the maximum North Atlantic MOC strength found at 1000 $2500 \mathrm{~m}$. Note that the $y$-axis scales differ across the three panels. Also shown is (c) the time series of the percentage volume of AABW remaining during the model simulation, with AABW defined as water colder than $0^{\circ} \mathrm{C}$ and deeper than $3000 \mathrm{~m}$. The thick $\mathrm{X}$ in (b) indicates the projected abyssal cell slowdown in the ACCESS1.0 coupled model in the absence of any meltwater forcing, and the confidence limits indicate the 1-std-dev spread across CMIP5 projections [taken from Heuzé et al. (2015)]. The percentage change of each quantity by 2200 is indicated in the right-hand side of each panel. Table 1 shows the corresponding percentage decline for the AABW and abyssal cells for the Merino-Depoorter and CORE experiments at $2050,2100,2150$, and 2200.

behavior in the response of AABW to meltwater input, we evaluate the AABW formation rate (defined, as above, as the maximum overturning south of $60^{\circ} \mathrm{S}$ and shallower than $2500 \mathrm{~m}$ ) for all three RCP scenarios as a function of both total cumulative and transient freshwater input rates in Fig. 4. This analysis reveals that the collapse in AABW appears to be triggered by a threshold value in the rate of meltwater input added around Antarctica ( $\sim 2-3 \times 10^{15} \mathrm{~kg} \mathrm{yr}^{-1}$; Fig. 4b) rather than the cumulative amount of freshwater added (Fig. 4a). This is consistent with past work evaluating hysteresis behavior in the response of North Atlantic Deep Water to surface freshening (Rahmstorf 2000; Rahmstorf et al. 2005; Hofmann and Rahmstorf 2009), although we note that the threshold value we obtain is likely dependent on model resolution (Spence et al. 2008; Condron and Winsor 2011) and other model parameters (Hofmann and Rahmstorf 2009).

In our model, AABW formation occurs both over the Antarctic shelf and in the open ocean in the Weddell Sea. However, in the meltwater addition experiments, the shelf convection is the first AABW formation region to be affected (Fig. 5a) because it is closer to the main source of added freshwater. In particular, the Antarctic shelf convection fully shuts down in the $\mathrm{FW}_{8.5}$ and $\mathrm{FW}_{4.5}$ experiments after 90 and 160 years, respectively, but persists to $\sim 70 \%$ of its original area in the $\mathrm{FW}_{2.6}$ experiment (Fig. 5a). By year 2200, the water-mass transformation for the convective regions over the shelf has collapsed for the higher density classes, namely neutral 


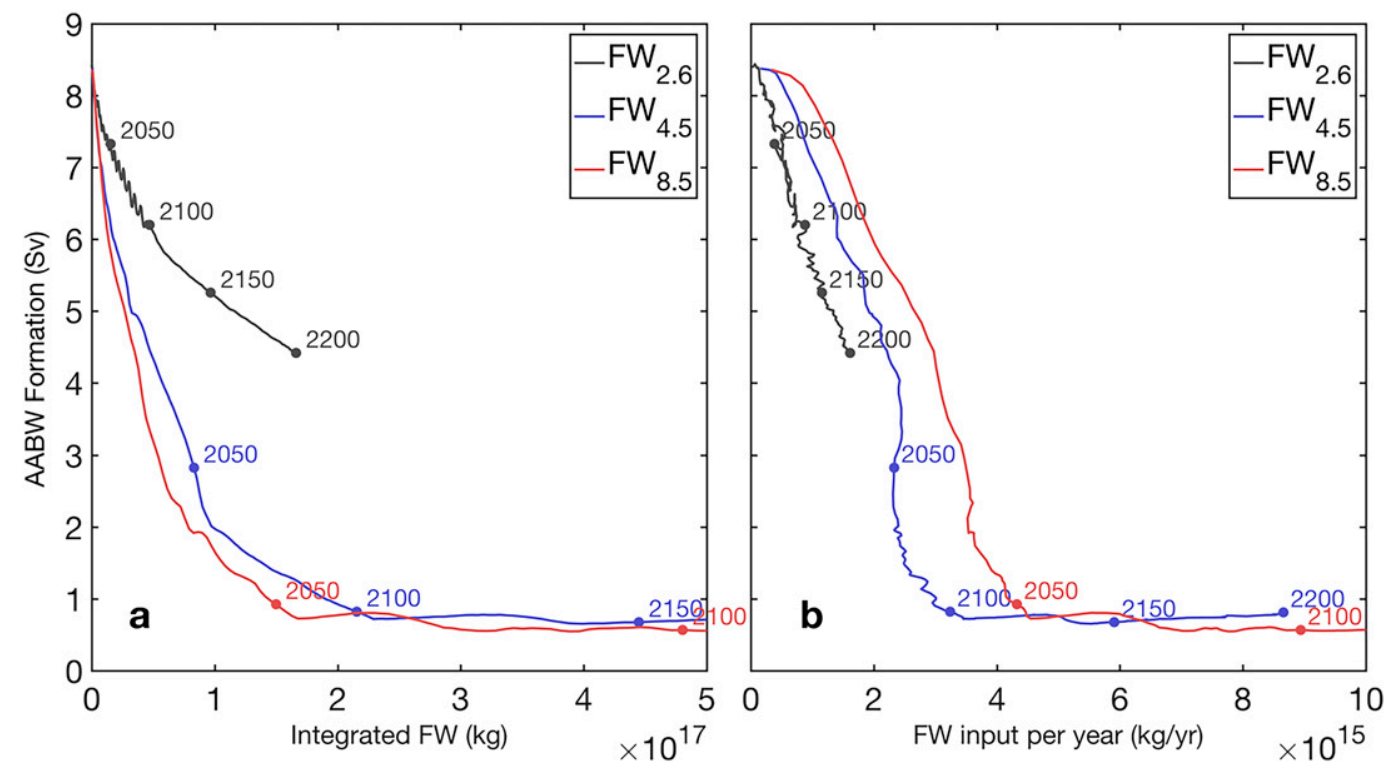

FIG. 4. Rate of AABW formation (Sv) for all three RCP scenarios as a function of (a) the integrated (cumulative) amount of freshwater added at the surface of the Southern Ocean and (b) the rate at which the freshwater is added at the surface (i.e., the added freshwater flux per year). Superimposed on the curves is an indication of the timeline of the experiments, shown at 50-yr intervals.

densities $>27.8 \mathrm{~kg} \mathrm{~m}^{-3}$, in the $\mathrm{FW}_{8.5}$ experiment (Figs. 5b,c). A similar collapse of the shelf-water overturn and abyssal water formation occurs in the $\mathrm{FW}_{4.5}$ experiment (not shown). Only in the $\mathrm{FW}_{2.6}$ experiment does some water-mass transformation remain over the shelf by 2200 ; however, this is only at a relatively light density class (not shown). On the other hand, the area of open-ocean convection initially increases in all three experiments (Fig. 5a). In $\mathrm{FW}_{4.5}$ and $\mathrm{FW}_{8.5}$ open-ocean convection eventually decreases to $\sim 85 \%$ of its initial area by 2200 , whereas in $\mathrm{FW}_{2.6}$ the open-ocean convection keeps increasing (Fig. 5a). The reason for this behavior is that shelf convection brings denser water to great depth over the open ocean, so when shelf convection reduces, the stratification over the open ocean also decreases, and thus more open-ocean convection can occur. However, in both $\mathrm{FW}_{4.5}$ and $\mathrm{FW}_{8.5}$, when the added freshwater eventually spreads over the Weddell Sea (by 2040-50) the local stratification increases again, which reduces the open-ocean convection. As measured by water-mass transformation rates (Figs. 5b,c), some of the open-ocean convection persists out to 2200 , unlike the collapse in shelf-water overturn. To summarize, because Antarctic shelf convection dominates AABW formation and is the variety of abyssal water most impacted by meltwater addition in our experiments, we can conclude that the shelf-convection response is the main driver for the collapse in AABW formation simulated.
To put these results in further context, it is worth noting that twenty-first-century CMIP5 projections, having no contribution of meltwater from ice-shelf and ice-sheet retreat, generally project a much weaker response to anthropogenic forcing. For example, the abyssal overturning at $30^{\circ} \mathrm{S}$ by year 2100 in the RCP 8.5 scenario in the CMIP5 multimodel mean decreases by just $\sim 2.2 \pm 2.6 \mathrm{~Sv}$ (from a baseline average of $10.0 \pm$ $6.7 \mathrm{~Sv}$; Heuzé et al. 2015) as compared with an 8.1-Sv decline (from initial conditions of $14.9 \mathrm{~Sv}$ ) simulated here. These values for our simulated abyssal overturning decline and initial condition are calculated using the abyssal cell strength at $30^{\circ} \mathrm{S}$ for consistency with the calculations of Heuzé et al. (2015). It should also be noted that our meltwater experiments include no other anthropogenic forcing, such as greenhouse gas-induced warming, so we could expect even greater rates of AABW decline in a fully forced future projection simulation. Some CMIP5 model projections even show an increase in abyssal overturning strength under the RCP8.5 scenario, with 5 models [of the 24 analyzed by Heuzé et al. (2015)] showing an increase by year 2100. Most of the remaining CMIP5 simulations they analyzed (11 of 19) exhibit only a very weak response $(<2 \mathrm{~Sv}$ decline) in the abyssal overturning cell, with only 5 models projecting an AABW decline of $>4 \mathrm{~Sv}$. Our meltwater simulations, which project a near collapse in AABW production by 2100 under both the RCP4.5 and RCP8.5 scenarios, 

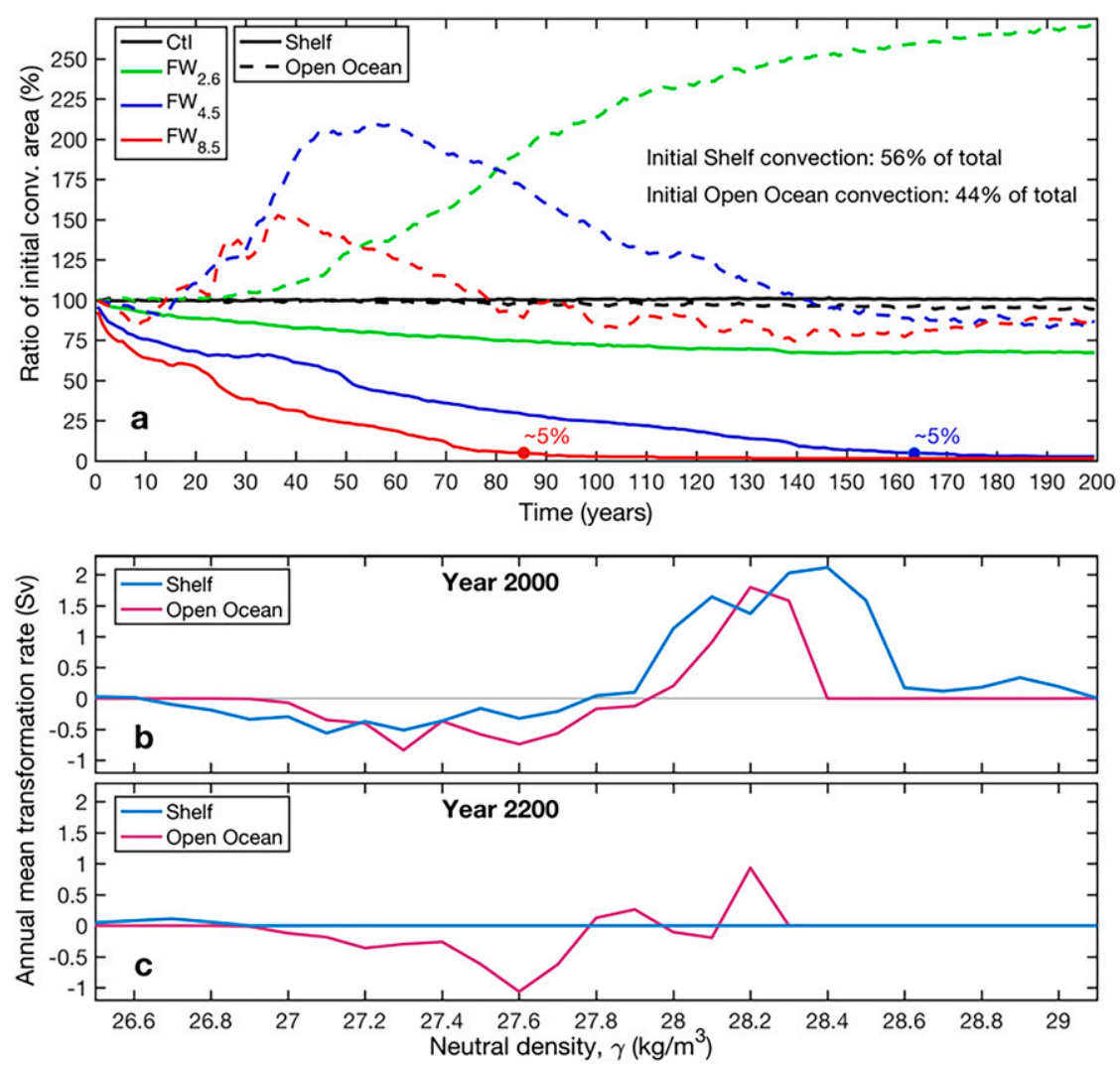

FIG. 5. (a) Time series of the surface area where convection occurs over the Antarctic shelf and over the open ocean. Shelf convection is defined as occurring wherever the ocean bathymetry is less than $1000 \mathrm{~m}$ and the maximum MLD is within the bottommost two grid cells. Open-ocean convection is defined as occurring where the maximum MLD is deeper than $2500 \mathrm{~m}$. The time at which the convection area diminishes to only $5 \%$ of its original value is highlighted with dots that match the experiment color. Also shown is annual mean water-mass transformation rate as a function of neutral density (Sv) for experiment FW8.5 at (b) 2000 and (c) 2200 for the open-ocean and shelf-convection areas.

thus suggest that CMIP5 projections for AABW slowdown are biased to be too weak as a result of missing freshwater input from melting ice sheets and ice shelves around Antarctica.

\section{b. Other overturning responses}

Elsewhere, NADW overturning exhibits a small but detectable strengthening in response to the added freshwater (Fig. 3d), which is likely due in part to the SSS restoring compensation, which leads to a slight increase in SSS globally. While the global-scale average SSS change outside of the Southern Ocean is small ( $\sim 0.1$ psu equally distributed in the $\mathrm{FW}_{8.5}$ experiment), localized differences in the North Atlantic can be as high as $0.8 \mathrm{psu}$, a consequence of both the restoring and upper-ocean circulation changes; this is sufficient to induce an increase in NADW overturning. The changes in upper-ocean circulation are due to the slight strengthening of NADW overturning, which brings saline subtropical water northward. The NADW increase comes about as a result of both the bipolar seesaw effect in response to AABW slowdown (Stocker et al. 1992; Broecker 1998; Stocker and Johnsen 2003) and the salinity compensation term. Elsewhere there is no significant change in the overturning circulation, with the wind-driven Deacon cell and the tropical overturning cells remaining largely invariant in strength across all of the experiments.

\section{c. Sensitivity to the location of applied meltwater anomaly}

The spatial pattern over which the freshwater anomalies are added has little effect on the rate of change of the meridional overturning circulation during the first 20-40 years of the model experiments (not shown). However, by 2200 , the CORE pattern leads to a more 
modest decline in AABW production. For example, the decline in the AABW and abyssal cells is weaker by $\sim 1.5-3 \mathrm{~Sv}$ in the CORE versions of the $\mathrm{FW}_{4.5}$ and $\mathrm{FW}_{8.5}$ experiments relative to the Merino-Depoorter versions (Table 1). By 2200 in the $\mathrm{FW}_{8.5}$ experiments, the AABW overturning cell slows down by $80 \%$ of its original value when applying meltwater using the CORE pattern, as compared with $97 \%$ collapse when using the Merino-Depoorter pattern. A similar response can be seen in the abyssal cell, with an $\sim 60 \%$ decline in strength when using the CORE pattern, and an $\sim 75 \%$ decline under the Merino-Depoorter pattern (by 2200 in the $\mathrm{FW}_{8.5}$ experiments). The weaker abyssal overturning decline using the CORE pattern occurs despite the fact that more freshwater gets added when adopting this pattern, because of the distribution of anomalies being restricted to the coastline in the absence of iceberg drift (Figs. 1a,b), leading to weaker compensation by the SSS restoring term in the CORE case. The reason this translates to a difference in impact on the overturning circulation is due to the magnitude of the applied freshwater anomalies relative to their proximity to the locations of convective overturning. In particular, when freshwater anomalies are added at the convection sites, as occurs in the Merino-Depoorter experiments, the most substantial reduction in AABW formation is simulated (Table 1). Similar findings on the importance of the meltwater location relative to the convection sites have been obtained in experiments applying freshwater fluxes in the North Atlantic (e.g., Rahmstorf 1995; Fichefet et al. 2003; Stouffer et al. 2006; Spence et al. 2013; Swindedouw et al. 2013) and in the Southern Ocean (Marsland and Wolff 2001; de Lavergne et al. 2014; Zanowski et al. 2015). Despite these differences in the magnitude of impact on the abyssal overturning circulation, the overall findings of this study are robust across both the CORE and Merino-Depoorter patterns of applied meltwater anomaly. In other words, the rate at which meltwater gets added around Antarctica has a stronger impact on the global ocean circulation than the precise location where the meltwater gets added. This supports the idealized forcing approach used recently by Bronselaer et al. (2018), although clearly the most appropriate projections would apply meltwater at the locations of most rapid ice-shelf and land-ice retreat around Antarctica.

\section{d. Volumetric analysis}

When defining AABW as water deeper than $3000 \mathrm{~m}$ and with potential temperature $<0^{\circ} \mathrm{C}$, the volume of AABW reduces by up to $48 \%$ by 2200 

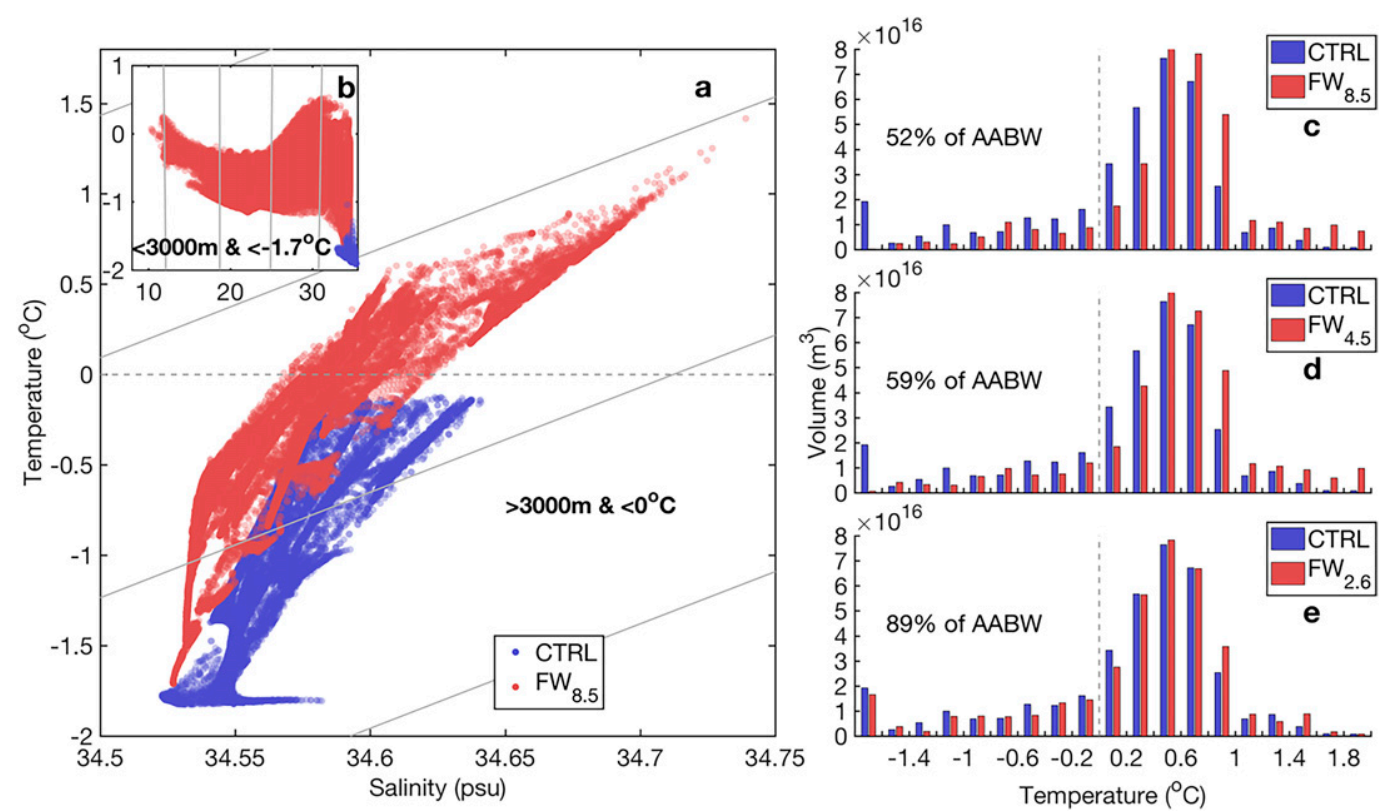

FIG. 6. (a) Temperature-salinity scatterplot of AABW properties in the control run (blue dots) and in the $\mathrm{FW}_{8.5}$ experiment (red dots) at the end of 2200. For the purposes of this analysis, AABW in the control experiment is defined as any water colder than $0^{\circ} \mathrm{C}$ and deeper than $3000 \mathrm{~m}$. (b) As in (a), but showing the grid cells that began in the control experiment as dense shelf water (defined as water shallower than $3000-\mathrm{m}$ and colder than $-1.7^{\circ} \mathrm{C}$ ). Also shown are volumetric temperature distribution of water deeper than $3000 \mathrm{~m}$ binned in $0.2^{\circ} \mathrm{C}$ increments, shown for the control experiment (blue) and for each of the three RCP FW experiments (red): (c) $\mathrm{FW}_{8.5}$, (d) $\mathrm{FW}_{4.5}$, and (e) $\mathrm{FW}_{2.6}$. The dashed gray line in (a), (c), (d), and (e) indicates the $0^{\circ} \mathrm{C}$ limit used to define the uppermost temperature for AABW, and the solid gray lines in (a) and (b) indicate isopycnal surfaces. The percentages shown in (c)-(e) indicate the proportion of AABW volume remaining at 2200 in each experiment.

with the addition of Antarctic meltwater in experiment $\mathrm{FW}_{8.5}$ (Figs. 6c-e). In response to the simulated collapse of $\mathrm{AABW}$ formation, the abyssal waters both warm and freshen (Fig. 6a), which leads to a significant volume of $\mathrm{AABW}$ warming above the $0^{\circ} \mathrm{C}$ threshold. This warming of the abyssal ocean progresses steadily over a multicentury diffusive time scale (Fig. 3c), contrasting the more rapid multidecadal decline in AABW production (Fig. 3a). In addition, the volumetric analysis reveals how Antarctic shelf water, which sinks when it is sufficiently cold and saline to form AABW, freshens and warms by 2200 (Fig. 6b). This warming and freshening constitutes a considerable change in the buoyancy of shelf water, leading to a shutdown in convective overturn of what was previously High Salinity Shelf Water and reduced AABW formation as previously described.

\section{e. Hydrographic changes}

The abyssal ocean generally becomes warmer and saltier in the $\mathrm{FW}_{4.5}$ and $\mathrm{FW}_{8.5}$ experiments due to the collapse of the AABW formation (Figs. 6 and 7). In contrast, in the $\mathrm{FW}_{2.6}$ experiment, with abyssal ocean ventilation persisting, there is a signature of interior freshening as the added meltwater at the ocean surface is convectively mixed to the bottom layers (Figs. 7a,d,g). Given recent estimates linking bottom water trends to warming and freshening at the sea surface (Azaneu et al. 2013; van Wijk and Rintoul 2014) rather than to a reduction in AABW ventilation rates, our $\mathrm{FW}_{2.6}$ experiment could be a proxy for the processes controlling present-day changes around Antarctica. This is perhaps not surprising given that Antarctic meltwater additions are thus far only a fraction of the future projected changes under any RCP scenario. This fresh lens of water mostly ventilates intermediate depths in the $\mathrm{FW}_{4.5}$ and $\mathrm{FW}_{8.5}$ experiments, with peak freshening at $\sim 1000-\mathrm{m}$ depth, although some freshening also appears in the ocean abyss, due to early twenty-first-century meltwater intrusions prior to the collapse of AABW formation (Fig. 7). Once the ventilation stops, the freshened deep ocean slowly becomes more saline due to abyssal mixing.

The simulated temperature changes in response to meltwater addition also largely reflect interior ocean adjustment to a collapse in AABW in experiments $\mathrm{FW}_{4.5}$ and $\mathrm{FW}_{8.5}$ (Fig. 8), with strong abyssal warming in the absence of ventilation by cold and fresh AABW. The bottom waters still warm in the $\mathrm{FW}_{2.6}$ experiment as a 


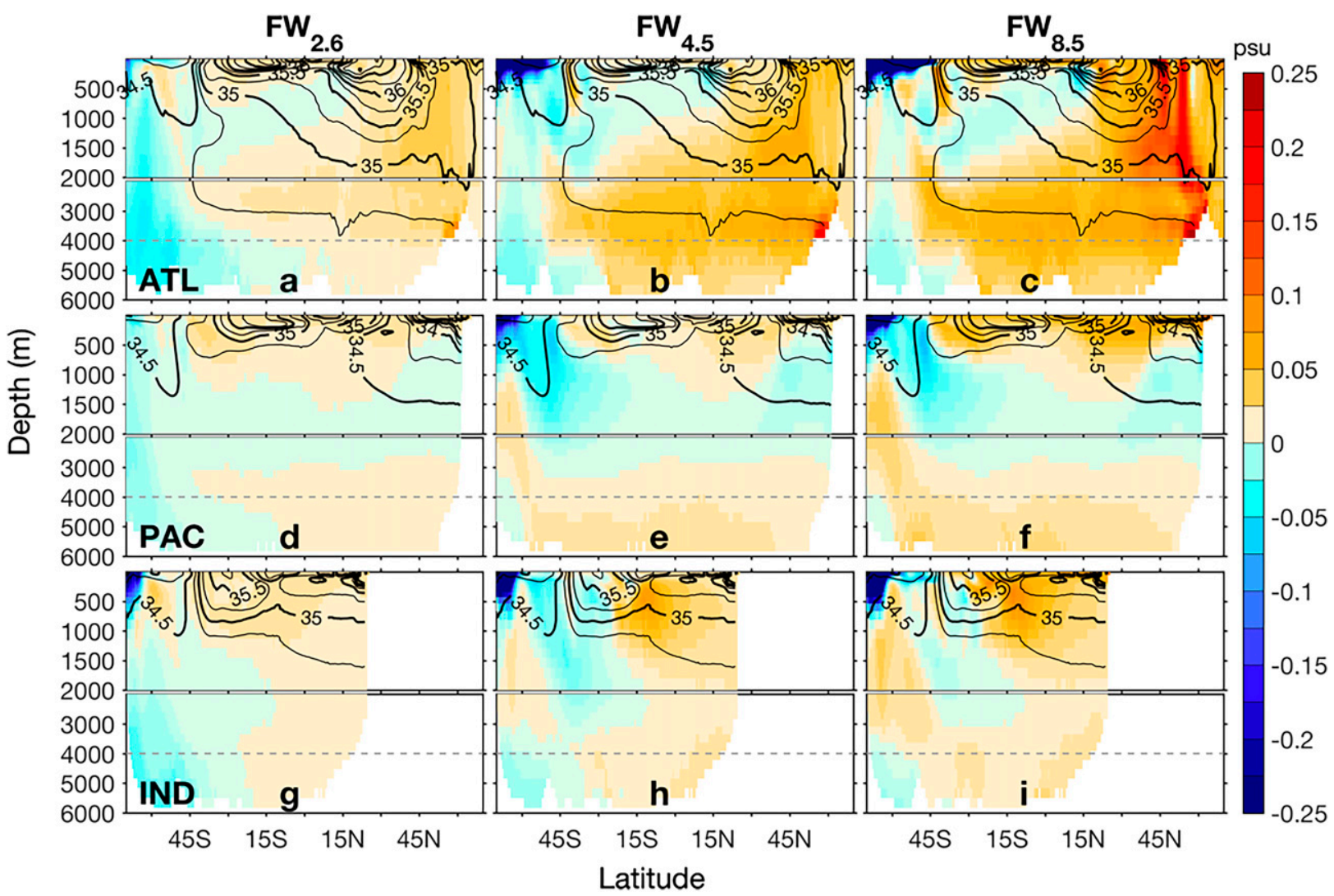

FIG. 7. Zonally averaged salinity change (psu) for the (a)-(c) Atlantic, (d)-(f) Pacific, and (g)-(i) Indian Ocean derived from the FW anomaly model experiments in year 2200, corresponding to meltwater scenarios for (left) RCP2.6, (center) RCP4.5, and (right) RCP8.5. The gray dashed lines show the 4000-m limit, which was used to calculate the thermal and haline expansion terms in Fig. 9.

result of reduced abyssal ventilation, but only by $0^{\circ}-0.3^{\circ} \mathrm{C}$ in the zonal average, in comparison with a $0.3^{\circ}-$ $1.2^{\circ} \mathrm{C}$ temperature increase in the $\mathrm{FW}_{4.5}$ and $\mathrm{FW}_{8.5}$ experiments (Fig. 8). The warming and increase in salinity between 0 and $4000 \mathrm{~m}$ in the North Atlantic in all experiments (Figs. 8a-c) is consistent with reduced AABW ventilation and the slight increase in NADW overturning previously discussed.

Southern Hemisphere mode waters get fresher and colder in all experiments (Figs. 6 and 7). This cooling and freshening is largely because the surface waters that form mode water are both fresher and colder (Fig. 9). The surface freshening is easy to understand, as SSS is reduced when the added meltwater makes its way northward to the location of deep wintertime mixed layers and mode water formation (Figs. 9a-c). The surface cooling (Figs. 9d-f) is due to shallower mixed layers (initiated by freshening) in a region of net ocean heat loss (Morrison et al. 2015; Purich et al. 2018). In the absence of other factors such as anthropogenic warming, shallower mixed layers in the mode water formation regions are more readily cooled during wintertime. These changes in the surface properties at the sites of mode water formation generally translate into cooler and fresher mode water in the ocean interior (Figs. 7 and 8).

\section{f. Steric sea level change}

In Fig. 10 we compare the pattern of sea level rise (SLR) due to the freshwater-induced abyssal warming and salinity change in our experiments. The SLR resulting from the direct addition of Antarctic meltwater would clearly dwarf this contribution from abyssal warming, but examining the pattern can shed light on the dynamics at play in the model simulations. The simulated thermosteric change due to the applied surface Southern Ocean freshening shows a remarkably similar pattern to the observed estimates of the thermal contribution to sea level rise during 1990-2010 from Purkey and Johnson (2010), with the most rapid rise on the western side of each ocean basin in the Southern Hemisphere, and maximum northward extent of significant positive trends in the Atlantic sector. This pattern reflects the pathways of most rapid ventilation by AABW in the abyssal ocean (e.g., Sen Gupta and England 2004; 


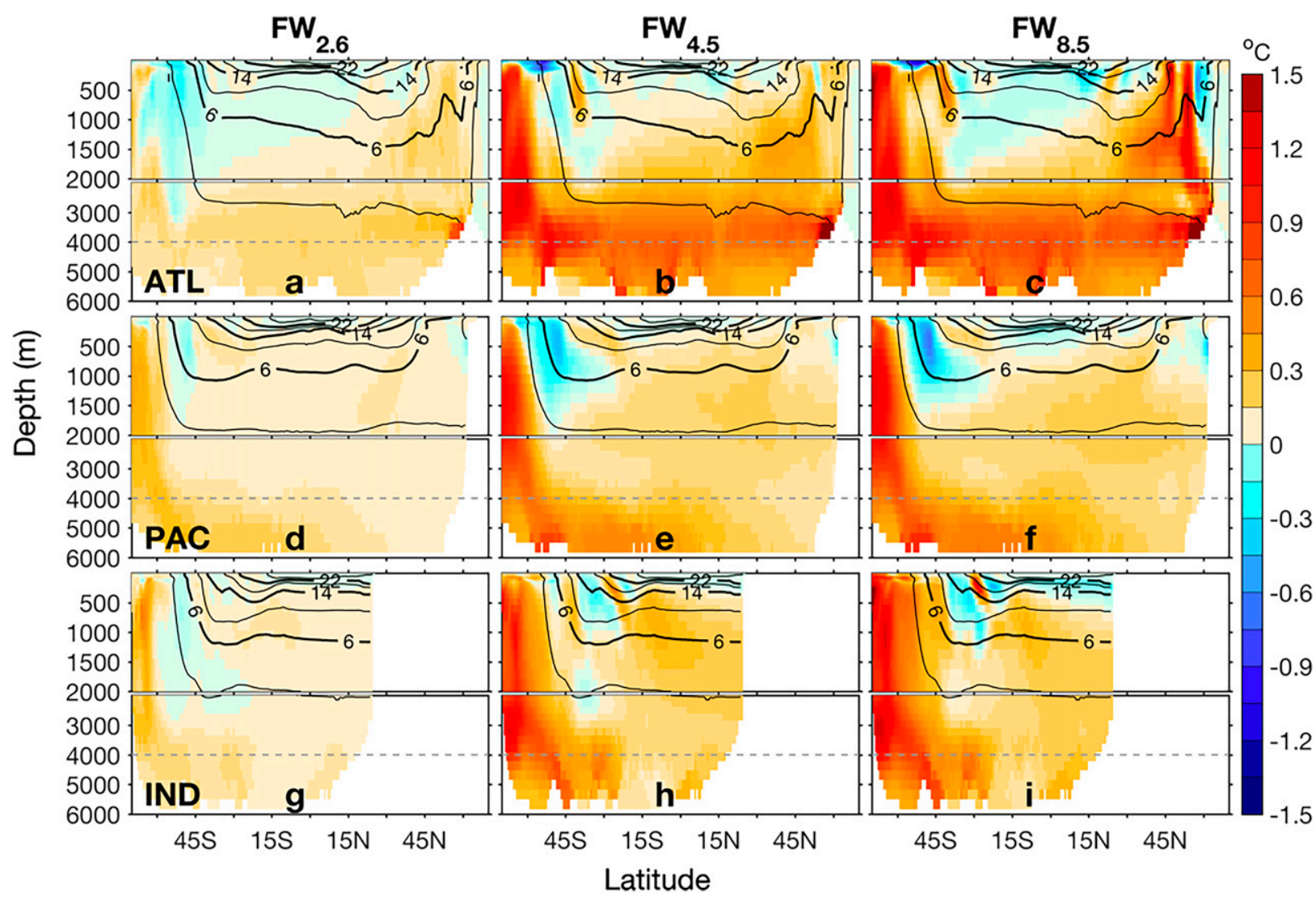

FIG. 8. As in Fig. 7, but showing zonally averaged temperature change $\left({ }^{\circ} \mathrm{C}\right)$.

Orsi et al. 1999). This suggests that the observed warming found by Purkey and Johnson (2010) could be an indication of a freshwater-induced slowdown in AABW formation over the last few decades. The model projected abyssal warming by 2200 shows changes equivalent to $1.5 \mathrm{~mm} \mathrm{yr}^{-1}$ SLR, with the highest rates of thermal expansion in the Atlantic Ocean (Fig. 10e).

Haline expansion due to abyssal freshening is strongest in the $\mathrm{FW}_{2.6}$ experiment (Figs. 10b,d,f), which is somewhat counterintuitive given the massive surface freshening induced by meltwater in the $\mathrm{FW}_{4.5}$ and $\mathrm{FW}_{8.5}$ experiments. However, this feature is easy to understand considering that $\mathrm{AABW}$ formation persists in the $\mathrm{FW}_{2.6}$ experiment, whereas in the $\mathrm{FW}_{4.5}$ and $\mathrm{FW}_{8.5}$ experiments AABW formation collapses (Fig. 3a). A sustained $\mathrm{AABW}$ cell in the $\mathrm{FW}_{2.6}$ experiment means that a substantial fraction of the added surface freshwater still gets into the abyssal layers in this experiment, as previously discussed (see Figs. 7a,d,g), inducing haline expansion. In contrast, a collapsed AABW cell in the $\mathrm{FW}_{4.5}$ and $\mathrm{FW}_{8.5}$ experiments means that the meltwaterinduced low-salinity water mostly remains at the sea surface, and the abyssal ocean becomes more saline in each basin in the absence of AABW ventilation (Fig. 7).
There is some haline expansion (between 0 and $0.3 \mathrm{~mm} \mathrm{yr}^{-1}$ ) in the Southern Ocean in the $\mathrm{FW}_{4.5}$ and $\mathrm{FW}_{8.5}$ experiments (Figs. 10d,f) as a result of substantial surface freshening and the legacy of meltwater overturn before the AABW formation collapsed (Fig. 7), but it is weaker than in the $\mathrm{FW}_{2.6}$ experiment.

Overall, both the thermosteric and halosteric SLR for the $\mathrm{FW}_{4.5}$ and $\mathrm{FW}_{8.5}$ experiments are of similar magnitude (Fig. 10), as is the overall change in interior ocean temperature and salinity in these two experiments (Figs. 7 and 8), consistent with their similar magnitude reduction in AABW volume (Figs. 6c,d) and decrease in abyssal overturning (Figs. 3a,b). As the AABW formation reduces or collapses, the abyssal ocean warms in each basin around the Antarctic margin; this warm signal then moves northward (Fig. 9), inducing abyssal thermal expansion globally (Figs. 10a,c,e).

\section{Summary and conclusions}

In this study we have employed a coupled ocean-sea ice model to investigate the potential long-term impacts of melting Antarctic ice on the ocean's overturning circulation, Antarctic water-mass properties, and the 

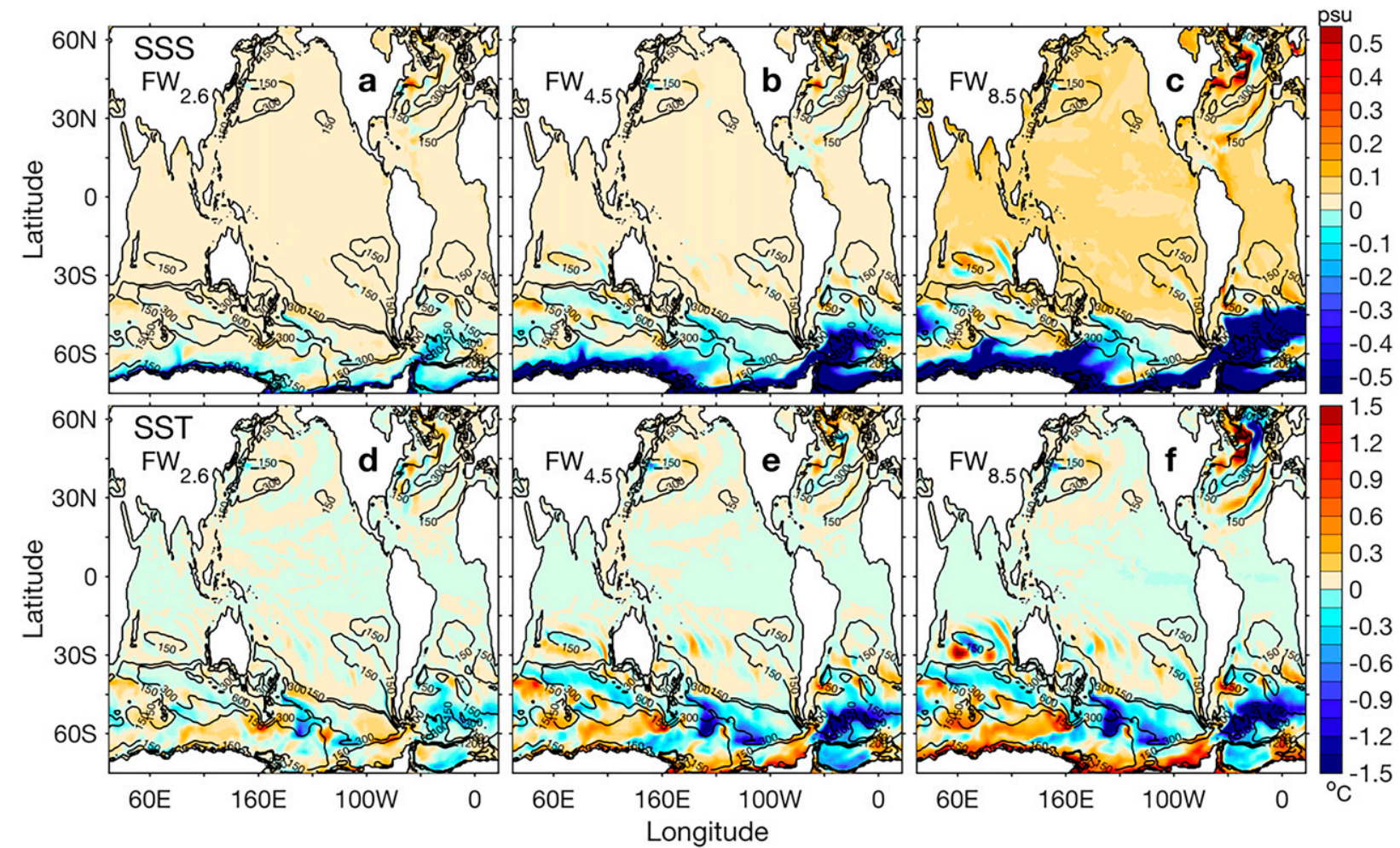

FIG. 9. (a)-(c) Sea surface salinity change (psu) and (d)-(f) sea surface temperature change $\left({ }^{\circ} \mathrm{C}\right)$ derived from the FW anomaly model experiments in 2200, corresponding to meltwater scenarios for (left) RCP2.6, (center) RCP4.5, and (right) RCP8.5. The black contours show the annual maximum MLD in the control experiment at 150-, 300-, 600-, and 1200-m contour levels.

associated heat uptake in the ocean abyss. The freshwater forcing pattern that we applied was derived from recent estimates of meltwater input from drifting icebergs and basal melt, combined with scenarios of projected amplification of Antarctic meltwater, to evaluate its long-term impact on ocean circulation. This study has particular relevance as none of the models participating in the CMIP5 future projections experiments included explicit meltwater contributions from ice-shelf and ice-sheet retreat. Overall, we find a rapid decline and eventual collapse in AABW production when RCP4.5 or RCP8.5 meltwater anomalies are included; in contrast, if emissions follow an RCP2.6 pathway, only a gradual slowdown in AABW production is simulated.

The formation of the densest variety of $\mathrm{AABW}$ in our model is formed over the shelf, with $74 \%$ of the abyssal water-mass transformation for neutral densities $>27.8 \mathrm{~kg} \mathrm{~m}^{-3}$ occurring over the shelf, and $100 \%$ for densities $>28.4 \mathrm{~kg} \mathrm{~m}^{-3}$ (Fig. 5b). As the meltwater from Antarctica is mostly added over the shelf, it is the shelf convection that is most affected by this perturbation, with this variety of AABW production collapsing in the RCP4.5 and RCP8.5 meltwater scenarios. The open-ocean convection, in contrast, initially increases in area due to the reduced stratification in the absence of shelf convection of abyssal dense waters. However, the open-ocean convection eventually reduces once the meltwater input reaches the open-ocean convective region in $\mathrm{FW}_{4.5}$ and $\mathrm{FW}_{8.5}$, but only by $\sim 15 \%$ of its original area. In contrast to the open-ocean response, all of the water-mass transformation occurring over the shelf fully shuts down in the $\mathrm{FW}_{4.5}$ and $\mathrm{FW}_{8.5}$ meltwater scenarios. Thus in our model, meltwater collapse of the AABW overturning relates almost exclusively to the shelf-water formation regions, not the open ocean. Considering that in reality virtually all AABW is formed over the Antarctic shelf, our experimental results bear some relevance to the observed system. Furthermore, our simulations also suggest that open-ocean convection-perhaps manifest as polynyas-could develop in reality if shelf convection is reduced, as a result of a decrease in Southern Ocean stratification in the absence of dense AABW formation.

Imposing different patterns for the input of additional Antarctic meltwater had little impact on the overall water-mass response. The CORE input pattern was limited to the Antarctic coastal runoff region, while the combined Merino-Depoorter pattern includes this coastal 


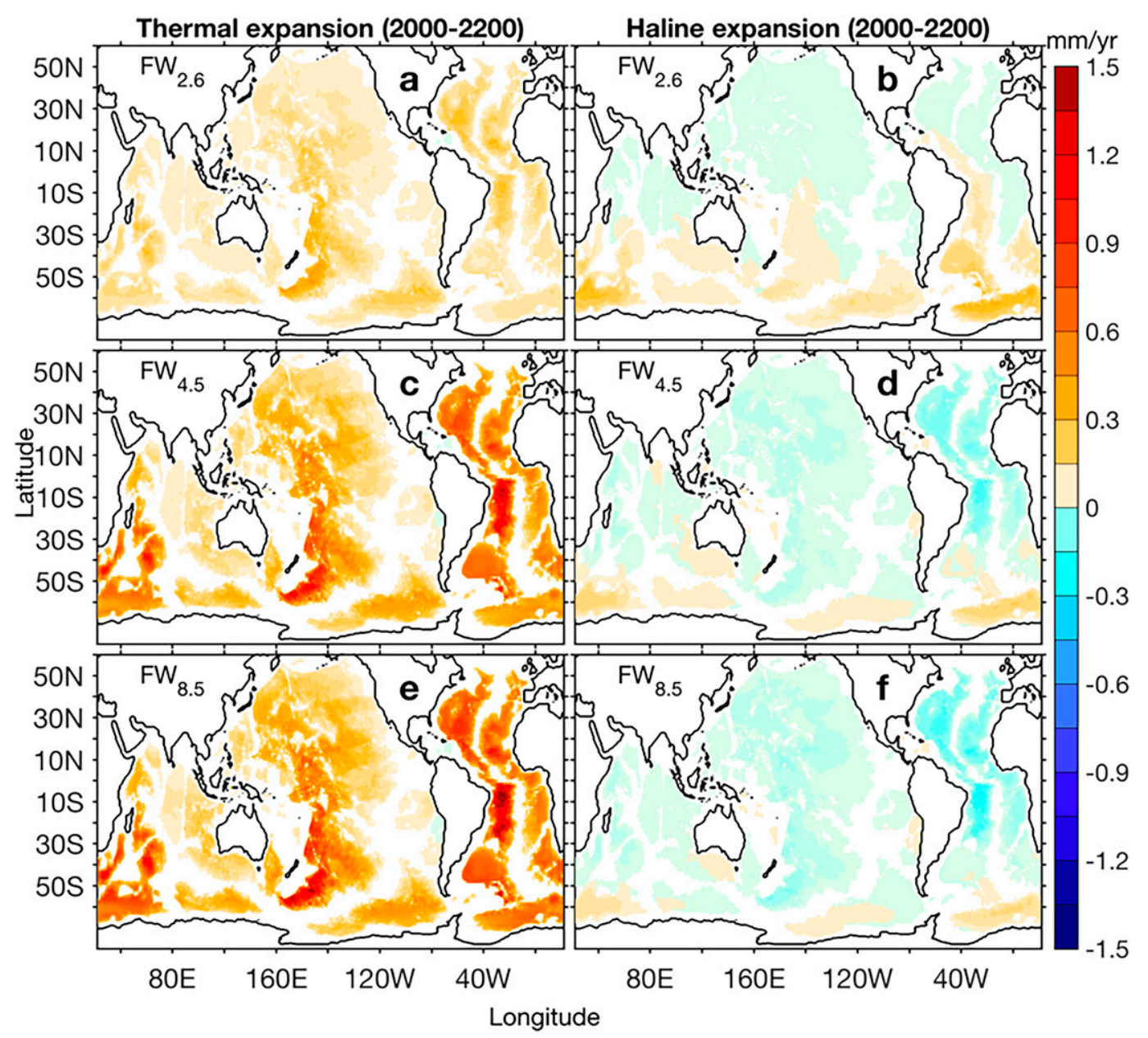

FIG. 10. Equivalent sea level rise $\left(\mathrm{mm} \mathrm{yr}^{-1}\right)$ due to abyssal steric height changes deeper than $4000 \mathrm{~m}$ : (left) thermal and (right) haline expansion derived from the FW anomaly model experiments in 2200 relative to 2000, corresponding to meltwater scenarios for (a),(b) RCP2.6, (c),(d) RCP4.5, and (e),(f) RCP8.5.

component as well as iceberg drift throughout the Southern Ocean. The wider spread in freshwater anomalies in the Merino-Depoorter pattern induces a slightly stronger slowdown of AABW overturning. However, the overall differences are small at this model resolution, and the main results of our simulations regarding circulation and water-mass changes are robust, regardless of the pattern of applied freshwater forcing. With the addition of the DeConto and Pollard (2016) RCP4.5 and RCP8.5 projected Antarctic meltwater anomaly in our model, we induce a near-complete shutdown of AABW formation within 30-60 years after the commencement of the additional freshwater flux. Under both the RCP4.5 and RCP8.5 scenarios, the change in surface buoyancy from the additional freshwater flux is sufficient to inhibit surface convective overturn and AABW formation. This result is obtained in a model that is typical of CMIP5 simulations in terms of model resolution, mixing schemes, and behavior. Yet the CMIP5 models do not resolve meltwater-induced changes in the abyssal ocean because they do not include ice-shelf and ice-sheet processes that lead to the estimated amplification of Antarctic meltwater found in DeConto and Pollard (2016) and other studies (e.g., Ritz et al. 2015; Golledge et al. 2015). Our study thus suggests that CMIP5 models could be drastically underestimating the response of AABW to future climate change. Here we examined the response to meltwater in isolation of other factors, most notably surface warming. In the future, the Southern Ocean is expected to warm at the surface; this would further impact surface buoyancy and thus the formation of AABW.

As the AABW formation collapses when adding Antarctic meltwater anomalies of a magnitude and rate expected under the RCP4.5 and RCP8.5 scenarios in our simulations, the AABW as defined today (i.e., potential 
temperature colder than $0^{\circ} \mathrm{C}$; Gordon 2001) heads toward extinction over a multicentury time scale. The much-reduced Antarctic meltwater fluxes under the RCP2.6 scenario show a more gradual decline in AABW overturning. This suggests that of the three scenarios considered, only RCP2.6, with drastic emissions reductions, can secure sustained AABW production over the long-term future. This result is obtained when considering only the effect of Antarctic meltwater, without the added buoyancy changes induced by surface warming, which would induce further slowdown. Note further that, even in this vastly mitigated RCP2.6 climate change scenario, AABW formation rates still decline substantially (by $\sim 30 \%-50 \%$ ) by 2200 . This suggests that AABW is likely to be considerably altered over the coming centuries, regardless of the rate of climate change and ice melt that we impose.

As the additional meltwater spreads away from the Southern Ocean at the surface, it increases buoyancy, reducing the mean MLD where mode water is formed. These regions of net heat loss thus cool as the volume within the MLD is reduced. The freshening and cooling of the ocean surface at the edge of the Southern Ocean results in fresher and cooler mode and intermediate waters. Under unmitigated global climate change, net radiative warming will almost certainly overwhelm this local cooling effect at the mode water formation sites, and thus this simulated cooling is probably only a characteristic of the idealized nature of these meltwaterforced experiments.

The pattern of abyssal steric SLR due to the amplification of Antarctic meltwater shows a striking resemblance to the Purkey and Johnson (2010) pattern of abyssal ocean warming already observed during 19902010. This suggests that a reduction in AABW formation might account for some of the changes seen in the abyssal ocean since 1990. With the reduction of AABW formation in our meltwater experiments, thermosteric sea level rises in each ocean basin via the warming induced in AABW. Like the observations of abyssal warming during 1990-2010, the strongest thermosteric SLR occurs in the Atlantic Ocean and nearest to Antarctica.

Recent observations have found that warming and freshening of $\mathrm{AABW}$ can occur in the absence of any significant changes in oxygen concentration (e.g., van Wijk and Rintoul 2014), suggesting that a reduction in AABW volume can be driven by changes in density class rather than reduced ventilation. Results from our $\mathrm{FW}_{2.6}$ experiment corroborate this hypothesis by showing both freshening and warming of the abyssal ocean in the presence of persisting, but weaker, AABW formation. In other words, the abyssal overturning remains sufficiently strong to inject meltwater anomalies to the bottom layers of the ocean. This supports the idea that a sufficiently gradual rate of surface freshening can drive changes in AABW properties, leading to volume loss within a given density class, while still being ventilated at a similar rate from the sea surface.

Formation of AABW is a key component of the ocean overturning circulation, regulating heat, carbon, freshwater, and nutrient transport on a global scale. A collapse in AABW production would profoundly impact the way the ocean interacts with the climate system, including the cryosphere, and it would drive a reduction in the recycling of nutrients from the seafloor into the upper ocean. In this study we have simulated a collapse in AABW formation within 30-60 years of adding Antarctic meltwater anomalies at a rate that matches transient projections under both the RCP4.5 and RCP8.5 scenarios. This has significant implications for abyssal ocean warming, salinity changes, nutrient recirculation, and global climate.

Acknowledgments. This work was supported by the Australian Research Council, including the ARC Centre of Excellence for Climate System Science (CE110001028). Author MHE is also supported by the Centre for Southern Hemisphere Oceans Research (CSHOR), a joint research center between QNLM, CSIRO, UNSW, and UTAS. Numerical simulations were conducted at the NCI National Facility systems at the Australian National University through the National Computational Merit Allocation Scheme supported by the Australian government. We thank Nacho Merino and Julien Le Sommer for generously providing their Antarctic iceberg melt climatology ahead of public release and the GFDL/NOAA for ongoing provision and support of the Modular Ocean Model (MOM). We acknowledge helpful discussions with Adele Morrison, Andy Hogg, Paul Spence, and other members of the COSIMA consortium (http://www.cosima.org.au).

\section{REFERENCES}

Agosta, C., X. Fettweis, and R. Datta, 2015: Evaluation of the CMIP5 models in the aim of regional modelling of the Antarctic surface mass balance. Cryosphere, 9, 2311-2321, https:// doi.org/10.5194/tc-9-2311-2015.

Azaneu, M., K. Rodrigo, M. M. Mata, and C. A. E. Garcia, 2013: Trends in the deep Southern Ocean (1958-2010): Implications for Antarctic Bottom Water properties and volume export. J. Geophys. Res. Oceans, 118, 4213-4227, https://doi.org/ 10.1002/jgrc.20303.

Beckmann, A., and R. Döscher, 1997: A method for improved representation of dense water spreading over topography in geopotential-coordinate models. J. Phys. Oceanogr., 27, 581-591, https://doi.org/10.1175/1520-0485(1997)027<0581: AMFIRO $>2.0 . \mathrm{CO} ; 2$. 
Bi, D., and Coauthors, 2013: ACCESS-OM: The ocean and sea ice core of the ACCESS coupled model. Aust. Meteor. Oceanogr. $J ., 63,213-232$, https://doi.org/10.22499/2.6301.014.

Brambilla, E., L. D. Talley, and P. E. Robbins, 2008: Subpolar Mode Water in the northeastern Atlantic: 2. Origin and transformation. J. Geophys. Res., 113, C04026, https://doi.org/ 10.1029/2006jc004063.

Broecker, W. S., 1998: Paleocean circulation during the Last Deglaciation: A bipolar seesaw? Paleoceanography, 13, 119-121, https://doi.org/10.1029/97PA03707.

Bronselaer, B., M. Winton, S. M. Griffies, W. J. Hurlin, K. B. Rodgers, O. V. Sergienko, R. J. Stouffer, and J. L. Russell, 2018: Change in future climate due to Antarctic meltwater. Nature, 564, 53-58, https://doi.org/10.1038/ s41586-018-0712-z.

Condron, A., and P. Winsor, 2011: A subtropical fate awaited freshwater discharged from glacial Lake Agassiz. Geophys. Res. Lett., 38, L03705, https://doi.org/10.1029/2010GL046011.

de Lavergne, C., J. B. Palter, E. D. Galbraith, R. Bernardello, and I. Marinov, 2014: Cessation of the deep convection in the open Southern Ocean under anthropogenic climate change. Nat. Climate Change, 4, 278-282, https://doi.org/10.1038/ nclimate2132.

DeConto, R. M., and D. Pollard, 2016: Contribution of Antarctica to past and future sea-level rise. Nature, 531, 591-597, https:// doi.org/10.1038/nature17145.

Depoorter, M. A., J. L. Bamber, J. A. Griggs, J. T. M. Lenaerts, S. R. M. Ligtenberg, M. R. van den Broeke, and G. Moholdt, 2013: Calving fluxes and basal melt rates of Antarctic ice shelves. Nature, 502, 89-92, https://doi.org/10.1038/nature12567; Corrigendum, 502, 580, https://doi.org/10.1038/nature12737.

Downes, S. M., and A. McC. Hogg, 2013: Southern Ocean circulation and eddy compensation in CMIP5 models. J. Climate, 26, 7198-7220, https://doi.org/10.1175/JCLI-D-12-00504.1.

Fichefet, T., C. Poncin, H. Goosse, P. Huybrechts, I. Janssens, and H. Le Treut, 2003: Implications of changes in freshwater flux from the Greenland ice sheet for the climate of the 21st century. Geophys. Res. Lett., 30, 1911, https://doi.org/10.1029/ 2003GL017826.

Fox-Kemper, B., and Coauthors, 2011: Parameterization of mixed layer eddies. III: Implementation and impact in global ocean climate simulations. Ocean Modell., 39, 61-78, https://doi.org/ 10.1016/j.ocemod.2010.09.002.

Gent, P. R., and J. C. McWilliams, 1990: Isopycnal mixing in ocean circulation models. J. Phys. Oceanogr., 20,150-155, https://doi. org/10.1175/1520-0485(1990)020<0150:IMIOCM >2.0.CO;2.

Golledge, N. R., D. E. Kowalewski, T. R. Naish, R. H. Levy, C. J. Fogwill, and E. G. W. Gasson, 2015: The multi-millennial Antarctic commitment to future sea-level rise. Nature, 526, 421-425, https://doi.org/10.1038/nature15706.

Gordon, A. L., 1971: Oceanography of Antarctic waters. Antarctic Oceanology I, J. L. Reid, Ed., Vol. 15, Antarctic research series, Amer. Geophys. Union, 169-203.

- 2001: Bottom water formation. Encyclopedia of Ocean Sciences, J. H. Steele, K. K. Turekian, and S. A. Thorpe, Eds., Academic Press, 334-340, https://doi.org/10.1006/ rwos.2001.0006.

Griffies, S. M., 2009: Elements of MOM4p1. NOAA/Geophysical Fluid Dynamics Laboratory Ocean Group Tech. Rep. 6, 444 pp., https://www.gfdl.noaa.gov/wp-content/uploads/files/model_ development/ocean/guide4p1.pdf.

, and R. W. Hallberg, 2000: Biharmonic friction with a Smagorinsky viscosity for use in large-scale eddy-permitting ocean models. Mon. Wea. Rev., 128, 2935-2946, https://doi.org/ 10.1175/1520-0493(2000)128<2935:BFWASL > 2.0.CO;2.

Heuzé, C., K. J. Heywood, D. P. Stevens, and J. K. Ridley, 2015: Changes in global ocean bottom properties and volume transports in CMIP5 models under climate change scenarios. J. Climate, 28, 2917-2944, https://doi.org/10.1175/JCLI-D-1400381.1 .

Hofmann, M., and S. Rahmstorf, 2009: On the stability of the Atlantic meridional overturning circulation. Proc. Natl. Acad. Sci. USA, 49, 20 584-20 589, https://doi.org/10.1073/ pnas.0909146106.

Hundsdorfer, W., and R. A. Trompert, 1994: Method of lines and direct discretisation: A comparison for linear advection. Appl. Numer. Math., 13, 469-490, https://doi.org/10.1016/01689274(94)90009-4.

Johns, W. E., and Coauthors, 2011: Continuous, array-based estimates of Atlantic Ocean heat transport at $26.5^{\circ} \mathrm{N}$. J. Climate, 24, 2429-2449, https://doi.org/10.1175/2010JCLI3997.1.

Johnson, G. C., S. G. Purkey, and J. M. Toole, 2008: Reduced Antarctic meridional overturning circulation reaches the North Atlantic Ocean. J. Geophys. Res., 35, L22601, https:// doi.org/10.1029/2008gl035619.

Killworth, P. D., D. Stainforth, D. J. Webb, and S. M. Paterson, 1991: The development of a free-surface Bryan-CoxSemtner ocean mode. J. Phys. Oceanogr., 21, 1333-1348, https://doi.org/10.1175/1520-0485(1991)021<1333:TDOAFS >2.0. $\mathrm{CO} ; 2$.

Kouketsu, S., and Coauthors, 2011: Deep ocean heat content changes estimated from observation and reanalysis product and their influence on sea level change. J. Geophys. Res., 116, C03012, https://doi.org/10.1029/2010JC006464.

Lago, V., S. E. Wijffels, P. J. Durack, J. A. Church, N. L. Bindoff, and S. J. Marsland, 2016: Simulating the role of surface forcing on observed multidecadal upper ocean salinity changes. J. Climate, 29, 5575-5588, https://doi.org/10.1175/JCLI-D-15 0519.1.

Large, W. G., and S. Yeager, 2004: Diurnal to decadal global forcing for ocean and sea ice models: The data sets and climatologies. NCAR Tech. Note NCAR/TN-460+STR, 105 pp., https://doi.org/10.5065/D6KK98Q6.

— , and - 2009: The global climatology of an interannually varying air-sea flux data set. Climate Dyn., 33, 341-364, https:// doi.org/10.1007/s00382-008-0441-3.

_ J. C. McWilliams, and S. C. Doney, 1994: Oceanic vertical mixing: A review and a model with a nonlocal boundary layer parameterization. Rev. Geophys., 32, 363-403, https://doi.org/ 10.1029/94RG01872.

Lee, H.-C., A. Rosati, and M. Spelman, 2006: Barotropic tidal mixing effects in a coupled climate model: Oceanic conditions in the northern Atlantic. Ocean Modell., 11, 464-477, https:// doi.org/10.1016/j.ocemod.2005.03.003.

Marsland, S. J., and J.-O. Wolff, 2001: On the sensitivity of Southern Ocean sea ice to the surface freshwater flux: A model study. J. Geophys. Res., 106, 2723-2741, https://doi.org/ 10.1029/2000JC900086.

Mathiot, P., A. Jenkins, C. Harris, and G. Madec, 2017: Explicit representation and parameterised impacts of under ice shelf seas in the $z^{*}$ coordinate ocean model NEMO 3.6. Geosci. Model Dev., 10, 2849-2874, https://doi.org/10.5194/gmd-102849-2017.

Merino, N., J. Le Sommer, G. Durand, N. C. Jourdain, G. Madec, P. Mathiot, and J. Tournadre, 2016: Antarctic icebergs melt over the Southern Ocean: Climatology and impact on sea 
ice. Ocean Modell., 104, 99-110, https://doi.org/10.1016/ j.ocemod.2016.05.001.

Morrison, A. K., M. H. England, and A. McC. Hogg, 2015: Response of Southern Ocean convection and abyssal overturning to surface buoyancy perturbations. J. Climate, 28, 4263-4278, https://doi.org/10.1175/JCLI-D-14-00110.1.

Orsi, A. H., J. C. Johnson, and J. L. Bullister, 1999: Circulation, mixing, and the production of Antarctic Bottom Water. Prog. Oceanogr., 43, 55-109, https://doi.org/10.1016/S0079-6611(99) 00004-X.

Purich, A., M. H. England, W. Cai, A. Sullivan, and P. Durack, 2018: Impacts of broad-scale surface freshening of the Southern Ocean in a coupled climate model. J. Climate, 31, 2613-2632, https://doi.org/10.1175/JCLI-D-17-0092.1.

Purkey, S. G., and G. C. Johnson, 2010: Warming of global abyssal and deep Southern Ocean waters between the 1990s and 2000s: Contributions to global heat and sea level rise budgets. J. Climate, 23, 6336-6351, https://doi.org/10.1175/2010JCLI3682.1. _, and - 2012: Global contraction of Antarctic Bottom Water between the 1980s and the 2000s. J. Climate, 25, 58305844, https://doi.org/10.1175/JCLI-D-11-00612.1.

Rahmstorf, S., 1995: Bifurcations of the Atlantic thermohaline circulation in response to changes in the hydrological cycle. Nature, 378, 145-149, https://doi.org/10.1038/378145a0.

_ 2000: The thermohaline ocean circulation-A system with dangerous thresholds? Climatic Change, 47, 247-256, https:// doi.org/10.1023/A:1005648404783.

_- and Coauthors, 2005: Thermohaline circulation hysteresis: A model intercomparison. Geophys. Res. Lett., 32, L23605, https://doi.org/10.1029/2005GL023655.

Redi, M. H., 1982: Oceanic isopycnal mixing by coordinate rotation. J. Phys. Oceanogr., 12, 1154-1158, https://doi.org/ 10.1175/1520-0485(1982)012<1154:OIMBCR >2.0.CO;2.

Ritz, C., T. L. Edwards, G. Durand, A. J. Payne, V. Peyaud, and R. C. A. Hindmarsh, 2015: Potential sea-level rise from Antarctic ice-sheet instability constrained by observations. Nature, 528, 115-118, https://doi.org/10.1038/nature16147.

Sarmiento, J. L., T. M. C. Hughes, R. J. Stouffer, and S. Manabe, 1998: Simulated response of the ocean carbon cycle to anthropogenic climate warming. Nature, 393, 245-249, https:// doi.org/10.1038/30455.

Sen Gupta, A., and M. H. England, 2004: Evaluation of interior circulation in a high-resolution global ocean model. Part I:
Deep and bottom waters. J. Phys. Oceanogr., 34, 2592-2614, https://doi.org/10.1175/JPO2651.1.

Simmons, H. L., S. R. Jayne, L. C. S. Laurent, and A. J. Weaver, 2004: Tidally driven mixing in a numerical model of the ocean general circulation. Ocean Modell., 6, 245-263, https://doi.org/ 10.1016/S1463-5003(03)00011-8.

Spence, J. P., M. Eby, and A. J. Weaver, 2008: The sensitivity of the Atlantic meridional overturning circulation to freshwater forcing at eddy-permitting resolutions. J. Climate, 21, 26972710, https://doi.org/10.1175/2007JCLI2103.1.

__ O. A. Saenko, W. P. Sijp, and M. H. England, 2013: North Atlantic climate response to Lake Agassiz drainage at coarse and ocean eddy-permitting resolutions. J. Climate, 26, 2651-2667, https:// doi.org/10.1175/JCLI-D-11-00683.1.

Stocker, T. F., and S. J. Johnsen, 2003: A minimum thermodynamic model for the bipolar seesaw. Paleoceanography, 18, 1087, https://doi.org/10.1029/2003PA000920.

—, D. G. Wright, and W. S. Broecker, 1992: The influence of high-latitude surface forcing on the global thermohaline circulation. Paleoceanography, 7, 529-541, https://doi.org/10.1029/ 92PA01695.

Stouffer, R. J., and Coauthors, 2006: Investigating the causes of the response of the thermohaline circulation to past and future climate changes. J. Climate, 19, 1365-1387, https://doi.org/ 10.1175/JCLI3689.1.

Sweby, P., 1984: High-resolution schemes using flux limiters for hyperbolic conservation laws. SIAM J. Numer. Anal., 21, 9951011, https://doi.org/10.1137/0721062.

Swindedouw, D., and Coauthors, 2013: Decadal fingerprints of freshwater discharge around Greenland in a multi-model ensemble. Climate Dyn., 41, 695-720, https://doi.org/10.1007/ s00382-012-1479-9.

van Wijk, E. M., and S. R. Rintoul, 2014: Freshening drives contraction of Antarctic Bottom Water in the Australian Antarctic Basin. Geophys. Res. Lett., 41, 1657-1664, https:// doi.org/10.1002/2013GL058921.

Wang, C., L. Zhang, S. Lee, L. Wu, and C. R. Mechoso, 2014: A global perspective on CMIP5 climate model biases. Nat. Climate Change, 4, 201-205, https://doi.org/10.1038/nclimate2118.

Zanowski, H., R. Hallberg, and J. L. Sarmiento, 2015: Abyssal ocean warming and salinification after Weddell polynyas in the GFDL CM2G coupled climate model. J. Phys. Oceanogr., 45, 2755-2772, https://doi.org/10.1175/JPO-D-15-0109.1. 